FITRAH Jurnal Kajian Ilmu-ilmu Keislaman

Vol. 04 No. 1 Juni 2018

e-ISSN : 2460-2345, p-ISSN: 2442-6997

Web: jurnal.iain-padangsidimpuan.ac.id/index.php/F

\title{
INTERNALISASI NILAI-NILAI TASAWUF DALAM SHALAWAT WAHIDIYAH BAGI PEMBENTUKAN KARAKTER MULIA (Studi Kasus di SMK Ihsanniat Rejoagung Ngoro Jombang)
}

\author{
ROFIATUL HOSNA \\ UNHASY Tebuireng Jombang \\ rofiatulhosna@gmail.com
}

\begin{abstract}
The purpose of this research is to know about the process of internalizing the values of Sufism in Shalawat Wahidiyah in SMK Ihsanniat Rejoagung Ngoro Jombang in shaping the character of their students. This study used a qualitative approach with the design of field research. The data collection techniques used: (1) observation, (2) interviews, and (3) documentation. Data were analyzed by data collection, data reduction, data presentation, drawing conclusions/verification. The results were obtained: First: practice activities Salawat Wahidiyah commonly known by the term Mujahadah. Second: The process of internalization of the values of Sufism Salawat Wahidiyah including through: Through Mujahadah that routinized, Prompts always read Nida 'either verbally or silently, Material kewahidiyahan and integration with other materials, training or upgrading Kewahidiyahan, GSDB (Movement conscious of giving box), Habits and models, and study the book of al-Hikam. Third: Generally, Characters students as a result of the internalization of Sufism Shalawat Wahidiyah in SMK Ihsanniat is good. Their character can be seen from several aspects: Attitude, emotions, beliefs, habits and self-conception. Fourth the environment, teachers and staff employees are compact, The spirit of the teachers and students, and Innovation Master Kewahidiyahan. While the inhibiting factors are: Facilities and infrastructure are inadequate, some outside students who have not become followers Wahidiyah, majority of teachers do not practice the Shalawat Wahidiyah and less administrative competencies of kewahidiyahan teacher.
\end{abstract}

Keywords: Tasawuf value, Shalawat Wahidiyah, and Noble Character.

\begin{abstract}
Abstrak
Penelitian ini memiliki tujuan untuk mengetahui proses internalisasi nilainilai sufi dalam shalawat wahidiah di SMK Ihsanniat Rejoagung Ngoro Jombang untuk pembentukan karakter siswa-siswa mereka. Penelitian dilakukan dengan menggunakan pendekatan kualitatif yang di disain dengan penelitian lapangan. Tehnik pengumpulan data dari penelitian ini melalui observasi, wawancara, dan dokumentasi, sementara data dianalisis melalui pengumpulan data, reduksi data, presentase data, dan menggambarkan kesimpulan. Dari hasil analisis data maka ditemukan beberapa hal, Pertama, pengamalan salawat wahidiyah di SMK Ihsanniat pada umumnya disebut dengan istilah Mujahadah. Kedua, proses Internalisasi nilai-nilai tasawuf dalam Salawat Wahidiyah bagi pembentukan karakter mulia siswa SMK Ihsanniat
\end{abstract}


FITRAH Jurnal Kajian Ilmu-ilmu Keislaman

Vol. 04 No. 1 Juni 2018

antara lain melalui: Mujahadah yang dirutinkan, Anjuran selalu membaca nida' baik secara lisan maupun dalam hati, Materi kewahidiyahan dan integrasi dengan materi lain, Diklat atau upgrading Kewahidiyahan, GSDB (Gerakan Sadar berDana Box), Kebiasaan dan keteladanan, dan pengajian kitab al-Hikam dan pendalaman Wahidiyah. Ketiga, Karakter siswa sebagai hasil internalisasi nilai tasawuf Salawat Wahidiyah di SMK Ihsanniat adalah baik, hal itu dapat dilihat dari beberapa aspek, yaitu: Sikap, emosi, kepercayaan, Kebiasaan dan Konsepsi diri. Faktor pendorong internalisasi nilai-nilai Salawat Wahidiyah di SMK Ihsanniat adalah lingkungan, Keempat, kekompakan antara kepala sekolah, Staf Guru serta karyawan dalam melakukan penginternalisasian nilai tasawuf Salawat Wahidiyah, semangat para guru dan siswa, dan inovasi Guru Kewahidiyahan. Sedangkan faktor penghambatnya adalah: Sarana dan prasarana yang kurang memadai, beberapa siswa luar yang belum menjadi pengamal wahidiyah, Mayoritas guru yang belum mengamalkan Salawat Wahidiyah dan kurangnya kompetesi administaratif guru kewahidiyahan.

Kata Kunci: nilai-nilai Tasawuf value, Shalawat Wahidiyah, and karakter mulia

\section{PENDAHULUAN}

Keberhasilan suatu bangsa dalam memperoleh tujuannya tidak hanya ditentukan oleh melimpah ruahnya sumber daya alam, tetapi juga sangat ditentukan oleh kualitas sumber daya manusianya. Bahkan ada yang mengatakan bahwa "Bangsa yang besar dapat dilihat dari kualitas/karakter bangsa (manusia) itu sendiri". ${ }^{1}$

Sejak 2500 tahun yang lalu, socrates telah berkata bahwa tujuan paling mendasar dari pendidikan adalah untuk membuat seseorang menjadi good and smart. Ini artinya pendidikan tidak mementingkan aspek intelektualitas saja, menjadi anak yang pintar, cerdas dan memiliki prestasi akdemik yang tinggi, namun juga menjadi orang yang baik, be good people or good person, yaitu menjadi orang yang memiliki akhlak yang baik dan berkarakter. Dalam sejarah Islam, sekitar 1400 tahun yang lalu, Muhammad SAW sang Nabi terakhir dalam ajaran Islam, juga menegaskan bahwa misi utamanya mendidik manusia adalah untuk menyempurnakan akhlak dan megupayakan pembentukan karakter yang baik (good character). Berikut ribuan tahun setelah itu, rumusan tujuan utama pendidikan tetap pada wilayah serupa, yakni pembentukan kepribadian manusia yang baik. ${ }^{2}$

\footnotetext{
${ }^{1}$ Abdul Majid dan Dian Andayani, Pendidikan Karakter Perspektif Islam, (Bandung: Remaja Rosdakarya, 2011), hlm. 2

${ }^{2}$ Abdul Majid dan Dian Andayani, Pendidikan Karakter.., hlm. 2
} 
Nabi Muhammad SAW dalam dakwahnya selain memperkenalkan Allah SWT sebagai satu-satunya Tuhan yang wajib disembah, beliau juga menuntun umatnya untuk berperilaku mulia dan memberikan teladan kepada mereka. Dengan sikap sabar dan keteguhan hati, beliau mampu mengubah moral yang telah rusak menjadi manusia yang berakhlak mulia. Usaha yang dilakukan dalam membina akhlak mereka benar-benar menjadi terwujud sebagai masyarakat yang bermoral dan beradab. Karakter yang paling menonjol dari kepribadian Nabi Muhammad SAW adalah akhlak yang tiada bandingannya.

Akhlakul karimah adalah tingkah laku dan budi pekerti yang luhur yang diridhai Allah SWT. al-Quran surat $A l-A h z a>b$, 33: 21 yang berbunyi:

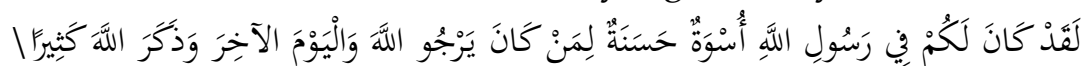

"Sesungguhnya pada diri Rasulullah SAW. terdapat contoh tauladan bagi mereka yang menggantungkan harapannya kepada Allah dan Hari Akhirat serta banyak berzikir kepada Allah." (Q.S. Al-Ahza>b [33]: 21)

Namun, pembangunan akhak yang dirintis oleh Rasulullah SAW melalui uswah hasanah yang diberikan oleh Rasulullah SAW lambat laun tergerus oleh zaman salah satunya oleh arus globalisasi. Menurut Hasan, Globalisasi merupakan fenomena dua dasawarsa belakangan ini, yang dipicu oleh kemajuan teknologi transportasi dan kemajuan ekonomi atau industrialisasi. ${ }^{3}$ Ia datang menembus batas-batas kedaulatan nasional setiap negara, baik itu negara maju maupun negara yang sedang berkembang. Arus globalisasi ini datangnya lebih cepat dan kuat. Pengaruh dari arus globalisasi ini dapat menjadikan lemahnya disiplin moral (akhlak).

Menurut Sudewo dalam buku Best Practice Character Building: Menuju Indonesia Lebih Baik, dijelaskan bahwa karakter adalah sejumlah sifat baik yang menjadi perilaku sehari-hari. ${ }^{4}$ Melalui membiasakan sifat baik, anda sedang melatih diri disiplin misalnya, begitu diterapkan artinya anda tengah "memperbaiki diri" yang tadinya malas bangun pagi, dengan membiasakan diri bangun sebelum shubuh maka proses "perbaikan diri" tengah dilakukan.

Pada umumnya siswa SLTA telah berada pada umur diantara 16-19 tahun, atau dapat dikatakan pada penggalan kedua masa remaja yang terkenal dengan masa remaja terakhir. Pertumbuhan pribadi dan social pada tahap umur ini,

${ }^{3}$ Muhammad Tholhah Hasan, Islam \& Masalah Sumber Daya Manusia, (Jakarta: Lantabora Press, 2014), hlm. 153.

${ }^{4}$ Erie Sudewo, Best Practice Character Building Menuju Indonesia Lebih Baik, (Jakarta: PT Gramedia, 2011), hlm. 45. 
FITRAH Jurnal Kajian Ilmu-ilmu Keislaman Vol. 04 No. 1 Juni 2018

ditandai dengan kebutuhan untuk menyatakan diri, ingin dihargai, diakui dan dipercayai oleh lingkungannya, terutama oleh teman-teman sebayanya. Mereka tidak mau dikucilkan dari kelompoknya, karena memerlukan teman untuk mengembangkan pribadinya. Keadaan seperti itulah yang sering mendorong remaja untuk mengikuti dan meniru apa yang dilakukan oleh temannya termasuk hal-hal negatif. ${ }^{5}$ Selain itu, berbagai macam psikotropika dan narkotika juga banyak beredar di kalangan anak sekolah. Lebih mengerikan, penjual dan pembeli juga adalah orang-orang yang masih berstatus siswa. ${ }^{6}$

Pembinaan akhlak melalui SLTA amat penting dan tidak mudah. terutama terhadap siswa yang pada tingkat pendidikan sebelumnya kurang mendapatkan bimbingan dan pembinaan akhlak secara cepat. ${ }^{7}$ Hal ini berarti pembinaan karakter atau akhlak tidak cukup pada tataran matter atau materinya saja melainkan bagaimana agar nilai-nilai agama mendarah daging (internalized values) dalam dirinya, lahir dan berbuah menjadi karakter yang mulia atau akhlakul karimah.

Akan tetapi dewasa ini, kehidupan modern menjadikan pengalaman keberagamaan sebagai sesuatu yang kian mahal, orientasi hidup manusia zaman modern ini yang lebih menekankan pada hal-hal yang bersifat fisik-material menjadikan aspek keberagamaan cenderung berada dalam wilayah pinggiran. Tidak hanya banyak waktu dan energi yang diberikan untuk menggeluti tentang tujuan dan makna hidup. Padahal, sebagaimana ditegaskan oleh Betrand Russel, manusia tidak mungkin hidup dengan kejiwaan yang aman tentram tanpa keinsyafan akan makna dan tujuan hidup itu sendiri. ${ }^{8}$

Muhammad Muhyiddin dalam bukunya yang berjudul "Kecerdasan Jiwa: rahasia memahami dan mengobati sakit dalam jiwa" mengatakan bahwa akhlak tidak dapat dipisahkan dari jiwa. ${ }^{9}$ Larinya akhlak dari jiwa berarti menghampakan agama dari jiwanya sendiri. Larinya akhlak dari manusia, berarti turunnya derajat manusia yang lebih rendah dari pada binatang. Terwujudnya akhlaq al-

\footnotetext{
${ }^{5}$ Furqona, Rama, Pendidikan Agama dan Akhlak Bagi Anak dan Remaja, (Ciputat: Logos Wacana Ilmu, 2001), hlm. 25-27.

${ }^{6}$ Abdul Majid dan Dian Andayani, Pendidikan Karakter Perspektif Islam, (Bandung: Remaja Rosdakarya, 2011), hlm. 5

${ }^{7}$ Abdul Majid dan Dian Andayani, Pendidikan Karakter..., hlm. 27

${ }^{8}$ Ahmad Sauqi, Meraih Kedamaian Hidup: Kisah spiritualitas Orang Modern, (Yogyakarta: Teras, 2010), hlm. 5

${ }^{9}$ Ahmad Muhyiddin, Kecerdasan Jiwa: Rahasia Memahami dan Mengobati Sakit dalam Hati, (Yogyakarta: Arruz Media, 2005), hlm. 65
} 
kari<mah sesungguhnya merupakan bukti keberhasilan seseorang dalam mencapai titik tengah kecenderungan-kecenderungan jiwa.

Istilah lain dari jiwa adalah hati, di mana segala kegiatan dan perbuatan manusia baik kegiatan lahiriyah maupun batiniyah, perbuatan yang baik ataupun perbuatan yang buruk digerakkan oleh intuisi suara hatinya. Hati nurani atau intuisi merupakan tempat di mana manusia dapat memperoleh saluran ilham dari Tuhan. Hati nurani ini diyakini selalu cenderung kepada kebaikan dan tidak suka kepada keburukan. Atas dasar inilah muncul paham atau aliran intuisisme. ${ }^{10}$

Hati merupakan "Pusat Komando" dan "Decision Maker" pembuat keputusan segala macam gerak dan aku manusia. Di dalam hati manusia bermarkas dua macam "Dewan" yang saling bertolak belakang, saling berlawanan. "Dewan Perancang Kejahatan" dan "Dewan Perancang Kebaikan". Siapa yang dominan menguasai hati, akan menjadi "Komandan" segala apa yang dilakukan.

ان في الجسد لمضغة اذاصلحت صلح الجسد كله و اذا فسدت فسدالجسد كله الاوهي القلب (رواه البخاري ومسلم عن

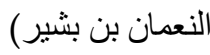

Artinya: "Perhatikanlah sesungguhnya di dalam jasad itu ada segumpal daging, jika segumpal daging itu baik, menjadi baik pula seluruh jasad, dan pabila kotor atau rusak, menjadi rusak pula seluruh jasad. Ketahuilah, yaitu Hati (HR. Bukhori Muslim dari Nu'man bin Basyir).

Ilmu yang membahas tentang pembersihan hati dan ketentraman jiwa dalah tasawuf. Tasawuf merupakan upaya mencapai tujuan hidup guna meraih kejiwaan dan kehidupan yang aman tentram. Lebih lanjut Nur Cholis Majid (2007: 1) menyebutkan bahwa tasawuf adalah bagian dri syari'at Islam (perwujudan dari Ihsan), tasawuf merupakan salah satu kerangka dari ajaran Islam yang lain yaitu Iman dan Islam. Syekh Abdul Wahid Yahya, seorang filosof Muslim yang juga seorang sufi, berpendapat bahwa tasawuf merupakan suatu bagian yang prinsipal dalam agama Islam. Agama tanpa tasawuf akan pincang, bahkan menjadi serba pincang dari segi-segi yang tinggi, yakni pusat asasinya. ${ }^{11}$

${ }^{10}$ Abudin Nata, Akhlak Tasawuf dan Karakter Mulia, (Jakarta: Raja Grafindo Persada, 2013), hlm.

${ }^{11}$ Abdul Halim Mahmud, Tasawuf Di Dunia Islam, (Bandung: Pustaka Setia, 2002), hlm. 299 
FITRAH Jurnal Kajian Ilmu-ilmu Keislaman

Vol. 04 No. 1 Juni 2018

Namun realitas menunjukkan banyak orang yang enggan mengenal dunia tasawuf misalnya melalui jam'iyyah tariqah. Hal ini dikarenakan menurut mereka tasawuf terkesan kuno, sulit dilakukan, terlalu banyak aturan dan syarat, kurang praktis bahkan pelakunya adalah orang-orang yang sudah lanjut usia saja. Anak muda berpandangan mereka belum waktunya memasuki dunia tasawuf karena kehidupan mereka masih panjang. Oleh karena itu, diperlukan konsep tasawuf yang praktis, mudah dan dapat diterapkan serta diaplikasikan oleh semua kalangan usia dan kalangan masyarakat dimanapun dan kapanpun. Salah satu amaliyah untuk menjernihkan hati dalam dunia tasawuf adalah Salawat .

Dalam Hadist Rasulullah tertulis bahwa:

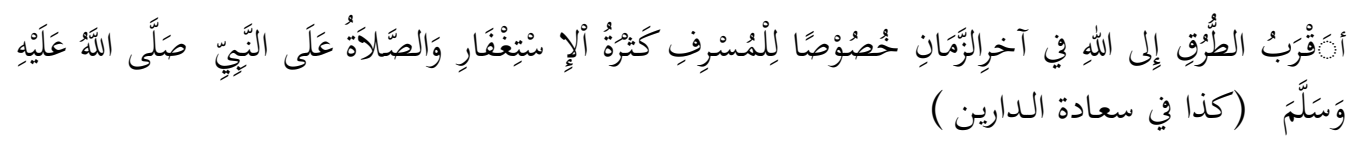

Artinya:

“Jalan yang paling dekat (menuju wushul) kepada Allah pada akhir zaman, khususnya bagi orang-orang yang berlarut-larut banyak dosa, adalah memperbanyak istighfar dan bacaan Salawat kepada Nabi SAW". (Dari kitab Sa`adatu ad-Darayni )

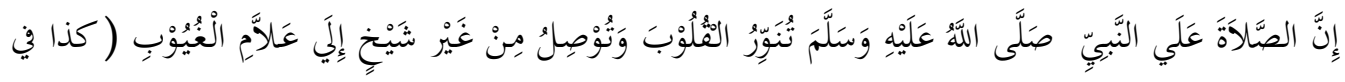

$$
\begin{aligned}
& \text { سعادة الدارين }
\end{aligned}
$$

Artinya: Sesungguhnya membaca Shalawat kepada Nabi SAW itu (dapat) menerangi hati dan mewushulkan (seseorang) tanpa Guru kepada Allah

Dzat Yang Maha Mengetahui segala yang ghaib. (Sa`ada>tu ad-Da>rayni, hal 36)

Margadinata dalam bukunya yang berjudul Spiritualitas S\{alawat menjelaskan bahwa, Menurut arti bahasa, pengertian Shalawat adalah doa, sedangkan menurut istilah, Salawat adalah Salawat Allah SWT kepada Rasulullah SAW, berupa rahmat dan kemuliaan (rahmat ta'dhim) Salawat dari malikat kepada Nabi, berupa permohonan rahmat dan kemuliaan kepada Allah SWT untuk Nabi Muhammad SAW. ${ }^{12}$

Salawat Wahidiyah adalah rangkain doa-doa Salawat Nabi SAW sebagimana tertulis di dalam lembaran Salawat Wahidiyah, termasuk kaifiyah (cara dan

${ }^{12}$ Wildana Margadinata, Spiritualias Salawat, (Malang: UIN-Maliki Press, 2010), hlm. 54-55 
adab/tata krama) dalam mengamalkannya. Salawat ini berfaedah menjernihkan hati, dan ma'rifat (sadar) kepada Allah SWT dan RasulNya. Salawat Wahidiyah termasuk salah satu dari ribuan Salawat ghoiru ma'thurah yaitu Salawat yang redaksinya bukan langsung dari Rasulullah SAW. Salawat ini juga tidak termasuk dalam kategori sebagai Jam'iyyah Tariqah, tetapi berfungsi sebagai tariqah dalam arti jalan menuju sadar kepada Allloh wa Rasulihi SAW. mengamalkan Salawat ini, tidak disertai syarat-syarat/ketentuan khusus yang mengikat, tetapi harus dengan adab (tatakrama): hudlur dan yakin kepada Allah SWT, mahabbah dan ta'dhim kepada Rasulullah SAW. ${ }^{13}$

Pengikut Salawat ini yang biasanya dikenal dengan sebutan pengamal Wahidiyah cukup banyak sampai ke pelosok negeri bahkan sampai manca negara seperti Malaysia, Brunai Darussalam, Australia, Suriname, Belanda, Arab Saudi, Jepang, Hongkong dll. ${ }^{14}$ Selain itu pengamal Wahidiyah tidak hanya para orang dewasa atau kaum sepuh saja melainkan terdapat pengamal anak-anak dan remaja sesuai dengan prinsip penyiaran S\{alawat ini yaitu "menyiarkan kepada siapa saja tidak pandang bulu sampai jami'al 'aalamiin"15

SMK Ihsanniat adalah salah satu lembaga formal dibawah Kementrian Pendidikan dan Kebudayaan (Kemendikbud) di wilayah Jombang yang dimiliki oleh para pengamal Wahidiyah. Sekolah ini merupakan salah satu lembaga di bawah naungan Yayasan Pendidikan Ihsanniat (YPI) Pesantren At-Tahdzib (PA) Ds. Rejoagung Kec. Ngoro Kab. Jombang Prov. Jawa Timur yaitu satu-satunya lembaga yang berani mengimplementasikan dan mengembangkan silabi pendidikan kewahidiyahan yang dibuat oleh DPP PSW. Dalam upaya pengintenalisasiannya, sekolah ini secara rutin dan berkesinambungan memasukkan dan membudayakan kegiatan-kegiatan kewahidiyahan seperti tasyafu'an bersama sebelum masuk kelas kemudian dilanjut dengan mujahadah

\footnotetext{
${ }^{13}$ DPP PSW, Kuliah Wahidiyah: untuk menjernihkan hati dan ma'rifat Billah wa Rosulih, (Jombang: Ed. XII, 2006), tt, 4-5

${ }^{14}$ Atik Mardiani Kholilah, Bendahara Badan Hubungan Luar Negeri Wahidiyah (BHLW) yaitu badan dibawah naungan Dewan Pimpinan Pusat Peyiar s\{alawa<t Wa<hidiyah (DPP PSW) yang khusus menangani pengamal Wahidiyah di luar negeri, wawancara pribadi, Ahad 06 Maret 2016

${ }^{15} \mathrm{Hal}$ ini diperkuat dengan adanya Badan khusus yang dibentuk oleh DPP PSW yaitu Badan Hubungan Luar Negeri yang tugas utamanya adalah melakukan penyiaran s\{alawa<t Wa<hidiyah di luar negeri dan memberikan pembinaan kepada para pengamal s\{alawa<t Wa<hidiyah di sana. Selain itu juga ada lembaran s\{alawa<t Wa<hidiyah dalam berbagai bahasa antara lain bahasa Inggris, Prancis, Jerman, Belanda, Indonesia, dan Arab pego. (Zainul Arifin, S.Pd.I.,: Sekretaris Umum DPP PSW, wawancara pribadi 09 Maret 2016).
} 
FITRAH Jurnal Kajian Ilmu-ilmu Keislaman

Vol. 04 No. 1 Juni 2018

muqodimah, melaksanakan mujahadah syahriyah, setiap satu bulan sekali, mengikuti pengajian al-Hikam setiap kamis legi di Pesantren At-tahdzib (PA) daan pendalaman wahidiyah di DPP PSW.

Selain itu, sekolah ini juga memasukkan materi kewahidiyahan dalam jam sekolah. Materi kewahidiyahan yang dimasukkan dalam muatan lokal tersebut cukup dimanati siswanya. Bahkan ada tidak sedikit anak yang sangat suka dengan materi ini. Dalam materi ini selain membahas tentang Shalawat Wahidiyah dan ajarannya juga dijelaskan bagaimana aplikasi materi tersebut dalam kehidupan sehari-hari serta beberapa kegiatan praktikum di kelas yang dapat menumbuh kembangkan karakter mulia siswa.

Hal lain yang menarik dari SMK yang didirikan sejak tahun 2003 ini adalah meskipun letaknya tidak berjauhan dengan sekolah lain setingkatnya, animo dan partisipasi masyarakat terhadap sekolah ini cukup besar. Hal ini terlihat dari jumlah siswa yang cukup besar, bangunan fisik yang berkembang secara signifikan, dan prestasi baik akademis maupun non akademis tidak hanya lokal bahkan sampai ke Jepang dengan menjalin kerjasama dengan Konjen Jepang di bidang pendidikan.

Dengan mengacu pada uraian di atas, penulis tertarik mengadakan penelitian di SMK Ihsanniat, yang kemudian dituangkan ke dalam judul "Internalisasi Nilai-nilai Tasawuf dalam Salawat Wahidiyah bagi Pembentukan Karakter Mulia (Studi kasus di SMK Ihsanniat Rejoagung Ngoro Jombang)

\section{METODE PENELITIAN}

Penelitian ini menggunakan pendekatan kualitatif. Instrumen penelitian ini adalah peneliti sendiri karena penelitian ini merupakan penelitian kualitatif. Sumber data dalam penelitian ini adalah informan, informannya adalah kepala sekolah, guru, siswa dan pihak lain yang terkait. Mengenai data dan sumber data yang digunakan pada penelitian ini peneliti menggunakan sampel purposif yaitu sampel yang memfokuskan pada informan-informan terpilih yang kaya dengan kasus untuk studi yang bersifat mendalam. Dalam penelitian ini, peneliti mengumpulkan data dengan Teknik wawancara, observasi, dan Dokumentasi. Teknik analisis data menggunakan teknik analisis deskriptif meliputi Reduksi Data (Data Reduction), Penyajian Data (Data Display), dan Verifikasi Data (Data Verification/Conclution Drawing). Selanjutnya, keabsahan data dalam penelitian ini 
ditentukan dengan menggunakan kriteria kredibilitas (derajat kepercayaan). Dalam menguji keabsahan data penelitian ini, peneliti menggunakan beberapa metode, diantaranya :

1) Perpanjangan keikutsertaan peneliti.

2) Ketekunan pengamatan

3) Triangulasi baik triangulasi dengan sumber, dengan teori, dengan penyidik dan dengan metode.

\section{TEMUAN DAN PEMBAHASAN}

Pengamalan Salawat Wahidiyah di SMK Ihsanniat Rejoagung Ngoro Jombang.

Kegiatan pengamalan Salawat Wahidiyah biasa dikenal oleh para pengamalnya dengan istilah Mujahadah. Mujahadah dalam Wahidiyah sebagaimana sering dijelaskan dalam diklat-diklat kewahidiyahan juga dalam buku-buku Wahidiyah adalah bersungguh-sungguh memerangi dan menundukkan hawa nafsu untuk diarahkan kepada kesadaran "Fafirruu Ilallah Wa Rasulihi SAW dengan mengamalkan Salawat Wahidiyah atau bagian dari padanya menurut adab, cara dan tuntunan yang diberikan oleh Muallif Salawat Wahidiyah Ra. sebagai penghormatan kepada Rasulullah SAW. dan sekaligus merupakan do'a permohonan kepada Allah SWT. bagi diri pribadi dan keluarga, baik yang masih hidup maupun yang sudah meninggal dunia, bagi bangsa dan negara, bagi para pemimpin bangsa dan negara di segala bidang, bagi ummat masyarakat segala bangsa dan negara serta para pemimpim mereka di segala bidang, dan umumnya bagi segala makhluk ciptaan Allah SWT. ${ }^{16}$

a. Adab-Adab Mujahadah

Diantara adab-adab dalam Mujahadah antara lain ${ }^{17}$ :

1) Dijiwai dengan ajaran wahidiyah, lilla $>h$ billa $>h$ dst

2) Hatinya hudur (berkosentrasi) kepada Allah Subhanahu Wata'ala,

3) Hudur = merasa hadir di Rasulullah SAW wa Ghauthi Hadhaz Zaman dengan ketulusan hati, ta'dhim (memuliakan) dan mahabbah (mencinta) sedalamdalamnya dan semurni-murninya

${ }^{16}$ Asmik Nasikhah, Guru Kewahidiyahan, Wawancara: 04 Agustus 2016 diperkuat dengan Dokumentasi Buku Tuntunan Muja>hadah dan Acara-acara Waahidiyah :DPP PSW, 2009, 3

${ }^{17}$ Wawancara Ibu Atikah, S.Ag, Guru PAI SMK Ihsanniat : 06 Agustus 2016 dan Asmik Nasikhah, 04 Agustus 2016 dan dipertegas juga dalam Buku Buku Tuntunan Muja>hadah dan Acaraacara Waahidiyah 
FITRAH Jurnal Kajian Ilmu-ilmu Keislaman

Vol. 04 No. 1 Juni 2018

4) Tadhallul: merendah diri merasa hina sehina-hinanya akibat perbuaatan dosanya

5) Tazallum: merasa penuh berlumuran dosa dan banyak berbuat dholim.

6) Iftiqar: merasa butuh sekali.

7) Disamping memohon untuk diri sendiri, sekeluarga, supaya memohon bagi ummat dan masyarakat, bangsa dan negara dan seterusnya.

8) Berkeyakinan bahwa Mujahadah /do'anya dikabulkan.

9) Bacaanya supaya tartil sesuai dengan makhroj, tajwid dan maad (panjang pendeknya ) serta tanda baca yang tepat.

10) Gaya, lagu, sikap dan cara melaksanakan Mujahadah supaya sesuai dengan tuntunan dari Muallif Salawat Wahidiyah Ra.

11) Jika mengalami suatu pengalaman bathin, tangis dan jeritan, apabila masih bisa dikuasai supaya dikuasai dan dimanfaatkan sekuat mungkin untuk lebih mendekat kepada Allah SWT dan Rasulullah SAW.

12) Ketika Mujahadah berjamaah suara makmum tidak boleh mendahului suara imam dan juga tidak boleh terlalu jauh ketinggalan.

13) Ketika melagukan Tashafu'an nada, gaya dan lagu harus seragam.

b. Aurod atau Wirid dalam Mujahadah

Aurad atau wirid dalam Mujahadah Wahidiyah sangat banyak sekali. Diantaranya aurod Mujahadah kecerdasan, keamanan, peningkatan, keuangan, kelancaran perjuangan, pertanian, lembaran, penyongsongan, 7-17, 3-1, 3-7, dan lain-lain. Selain itu Wahidiyah juga menerapkan bimbingan secara kontinyu sebagaimana yang juga dijadikan pedoman dan rujukan dalam pengimplementasiannya di SMK Ihsanniat, antara lain ${ }^{18}$ :

1) Mujahadah yang dibakukan seperti:

a) Mujahadah pengamalan 40 hari atau diringkas 7 hari

Mujahadah yang dilaksanakan selama 40 Hari atau 7 hari berturutturut dengan adab dan tata cara pengamalan yang telah dibimbingkan oleh Hadlrotul Muallifnya. Mujahadah ini dapat dilakukan sendiri-sendiri (munfaridan) tetapi lebih dianjurkan berjamaah sekeluarga, satu kampung/lingkungan. Mujahadah ini biasanya dilaksanakan ketika menyongsong Pelaksanaan Mujahadah Kubro atau pengamal baru atau

${ }^{18}$ Dokumentasi Buku Tuntunan Mujahadah dan Acara-acara Wahidiyah, (Jombang: DPP PSW, 2009), 5 dan diperkuat wawancara dengan Ibu Asmik Nasikhah, M.HI, Ibu Yusida, S.Pd., M.M., waka Humas SMK Ihsanniat dan Septi Jihan, Siswi Kelas XI AP Tapel 2015/2016, (09 Mei 2016) dan juga observasi pada bulan Agustus 2016 
boleh juga setiap hari dengan aurod lembaran. Mujahadah ini di SMK Ihsanniat tidak dilaksanakan pada waktu khusus di sekolah.

b) Mujahadah yaumiyyah (harian)

Dilaksanakan setiap hari paling sedikit satu kali dalam sehari semalam dengan urutan bacaan dalam "lembaran Salawat Wahidiyah" dan hitungannya boleh ditambah ditetapkan/ dikurangi sebagaian dari seluruh nya. Di samping menurut pilihanya sendiri seperti itu ada yang sangat dianjurkan. Yaitu, yang dikenal sebutan : "MUJAHADAH BILANGAN 7-17". Kegiatan ini dilakukan oleh seluruh siswa-siswi SMK Ihsanniat sebelum masuk kelas setiap hari.

c) Mujahadah keluarga.

Adalah Mujahadah berjamaah sekeluarga. Apabilah situasi mengizinkan dianjurkan agar dilaksanakan tiap hari satu kali, sukyur tiap waktu ba'da Sholat maktubah (fardlu). Setidak-tidak nya seminggu sekali/tiap Minggu sekali, atau tiap Bulan sekali. Mujahadah ini juga tidak dilaksanakan secara khusus di Sekolah.

d) Mujahadah Usbu'iyah (Mingguan)

Yaitu Mujahadah yang dilaksanakan seminggu sekali berjama'ah seluruh pengamal Wahidiyah satu kampung/lingkungan desa/keluarga, sekalipun Pengamal Wahidiyahnya hanya sedikit (dua/tiga Orang, misalnya).

Implementasinya di SMK Ihsanniat selain Mujahadah setiap hari pra masuk kelas (Mujahadah yaumiyah), siswa/siswi SMK Ihsanniat juga melaksanakan Mujahadah Usbuiyah yang dilaksanakan satu minggu sekali. Dalam pelaksanaanya Mujahadah ini dilakukan setelah upacara yang dilaksanakan seminggu sekali.

e) Mujahadah Syahriyah (bulanan)

Dilaksanakan tiap Bulan sekali/setiap 35 hari/selapan sekali oleh seluruh masyarakat Wahidiyah, pria, wanita, remaja, dan kanak-kanak sewilayah kecamatan dengan mengundang serta masyarakat umum segala lapisan, golongan dari tingkatan.

Di SMK Ihsanniat, Mujahadah ini dilaksanakan sesuai dengan namanya yaitu sebulan sekali. Berbeda dengan pelaksanaan Mujahadah yaumiyah dan Mujahadah usbuiyah, Mujahadah syahriyah ini dilaksanakan secara resmi atau acara ceremonial. Dimana dalam acara ini 
FITRAH Jurnal Kajian Ilmu-ilmu Keislaman

Vol. 04 No. 1 Juni 2018

ada susunan acaranya mulai dari MC s.d. Kuliah Wahidiyah. Para petugas acara dalam Mujahadah ini diambil dan dilaksanakan oleh siswa siswi SMK Ihsanniat secara mandiri.

f) Mujahadah Rubu'ussanah (tribulan)

Mujahadah ini dilaksanakan empat kali dalam setahun atau tiga bulan sekali (triwulan). Namun pelasanaannya tidak disekolah, melainkan mengikuti Dewan Pimpian Cabang Penyiar Salawat Wahidiyah (DPC PSW) masing-masing yakni sesuai dengan domisili masing-masing siswa. Jika mereka di Pondok berarti mereka mengikuti aturan atau jama'ah yang ada di pondok tetapi jika mereka dirumah berarti mereka mengikuti aturan pengurus PSW yang ada dirumah.

g) Mujahadah Nishfussanah

Dalam buku Tuntunan Mujahadah disebutkan bahwa Nisfussanah dilaksanakan tiap 6 Bulan sekali oleh seluruh Pengamal Wahidiyah pria, wanita, remaja dan kanak-kanak Sewilayah Propinsi/Daerah khusus daerah Istimewa dengan mengundang masyarakat.

Jadi Mujahadah ini level provinsi. Meskipun tidak dilaksanakan di wilayah SMK Ihsanniat dan SMK juga bukan penyelenggara, tapi SMK ini sangat mendukung pelaksanaanya. Bahkan sekolah akan meliburkan siswanya jika Mujahadahnya diselenggarakan ditempat yang jauh dan perjalannannya dari pagi hari, seperti Banyuwangi, Jember, Pacitan, Madura dsb.

h) Mujahadah Kubro

Mujahadah kubro adalah even terbesar bagi para pengamal wahidiyah. Para pengamal di seluruh Indonesia bahkan diluar negeri akan hadir dalam rangka do'a bersama untuk keberkahan dan keselamatan bangsa dan negara. Mujahadah ini dilaksanakan dua kali dalam setahun. Yaitu setiap bulan Muharram dalam rangka memperingati hari lahirnya Salawat Wahidiyah dan setiap bulan Rajab untuk memperingati isra' mi'raj Rasulullah SAW juga sekaligus memperingati Haul beliau muallif Salawat Wahidiyah.

Mujahadah ini diselenggarakan oleh DPP PSW di Halaman Pesantren At-Tahdzib (PA). Dikarenakan acara ini diselenggarakan di PA dan sekitarnya, maka seluruh santri dan siswa yang berada di bawah naungan Yayasan Pendidikan Ihsanniat (YPI) diliburkan guna ikut 
membantu mensukseskan pelaksanaan acara tersebut juga agar lebih fokus pada acara tersebut. Acara ini biasanya juga dimanfaatkan para siswa untuk ajang kreasi dan karya misalnya membuka stand pernakpernik ala wahidiyah atau membuka Kantin SMK Ihsanniat atau sekedar menunjukkkan hasil karya SMK Ihsanniat.

2) Mujahadah Waqtiyah

Adalah kegiatan Mujahadah serempak yang dilaksanakan pada waktuwaktu tertentu atau ketika ada suatu kepentingan. Beliau Muallif Wahidiyah, Ra. telah memberikan tuntunan dan bimbingan tentang berbagai macam Mujahadah Waqtiyyah, antara lain: Mujahadah Peringatan Tahun Baru Hijriyah dan Masihiyah, Mujahadah Peringatan Ulang Tahun Kemerdekaan RI, Mujahadah Peringatan Hari-Hari Besar Nasional, Mujahadah Malam Nishfu Sya'ban, Mujahadah Peringatan Nuzulul Qur'an, Mujahadah Malam Idhul Fitri, Mujahadah Dimakam (Kubur) Dalam Bulan Syawal, Mujahadah Membarengi Wukufnya Hujjaj Di Arafah, Mujahadah Menyongsong Suatu Peristiwa Penting.

3) Mujahadah Khusus

Mujahadah yang dilaksanakan secara khusus sehubungan dengan adanya hal-hal yang khusus dan dengan aurod Mujahadah yang khusus pula. Beliau Mualif Wahidiyah, Ra. Wa Qs. telah memberikan bimbingan dan Ijazah kepada para pengamal Wahidiyah tentang pelaksanaan dan Aurod MujahadahMujahadah khusus. Antara lain sebagai berikut; Mujahadah Khusus Peningkatan, Mujahadah Khusus Penyongsongan Suatu Acara, Mujahadah Khusus Keamanan, Mujahadah Khusus Kecerdasan, Mujahadah Khusus Pembangunan, Mujahadah Khusus Istikhoroh, Mujahadah Khusus Pertanian, Mujahadah Khusus Permohonan Suatu Hajat.

Selain Mujahadah- Mujahadah di atas, siswa SMK Ihsanniat bersama lembaga pendidikan yang berada di bawah YPI Ihsanniat juga secara rutin melaksanakan Mujahadah sebagai berikut:

1) Mujahadah di makam pendiri pesantren at-Tahdzib yang dilaksanakan secara mandiri dan menurut kesadaran pribadi oleh para siswa SMK sekaligus santri at-Tahdzib.

2) Mujahadah di makam Muallif Salawat Wahidiyah di Kediri. Kegiatan ini dilaksanaka seminggu sebelum ujian Nasional dan diikuti oleh seluruh 
FITRAH Jurnal Kajian Ilmu-ilmu Keislaman

Vol. 04 No. 1 Juni 2018

siswa kelas III dan dewan guru yang berada di bawah naungan YPI Ihsanniat.

\section{Internalisasi nilai-nilai tasawuf dalam Salawat Wahidiyah bagi pembentukan karakter mulia di SMK Ihsanniat Rejoagung Ngoro Jombang.}

Langkah-langkah pembentukan karakter melalui internalisasi nilai-nilai tasawuf Salawat Wahidiyah di SMK Ihsanniat ${ }^{19}$

1. Melalui Mujahadah yang dirutinkan

2. Anjuran selalu membaca nida' baik secara lisan maupun dalam hati yaitu " $Y a$ sayyidi ya Rasulallah". (Duhai pemimpin kami, duhai utusan Allah).

3. Materi kewahidiyahan dan integrasi dengan materi lain

Materi pelajaran kewahidiyahan adalah sebuah materi pelajaran muatan lokal (mulok) yang membahas tentang segala seluk beluk wahidiyah. Diantara materi-materi yang disampaikan dalam mulok ini adalah: Sholawat dan dasar hukumnya, pendapat ulama' tentang sholawat, Salawat Wahidiyah dan ajarannya, Mujahadah dan adab-adab serta macam-macamnya, sejarah wahidiyah, organisasi Wahidiyah dll.

4. Diklat atau upgrading Kewahidiyahan

Diklat atau upgrading tentang Kewahidiyahan ini dilaksanakan setiap tahun oleh Yayasan Pendidikan Ihsanniat. Kegiatan ini dilakukan setelah ujian Nasional. Sasaran peserta upgrading ini adalah seluruh siswa kelas 3 yang berada dibawah naungan Yayasan pendidikan Ihsanniat termasuk SMK Ihsanniat. Kegiatan ini dimaksudkan agar setelah mereka lulus sekolah mereka memiliki bekal tentang materi kewahidiyahn yang tentunya nanti sekembali mereka ke daerah masing-masing materi tersebut akan sagat berguna dalam mengatasi problematika perjuangan Wahidiyah di daerahnya.

5. GSDB (Gerakan sadar berdana Box)

Dana Box merupakan'"paket tarbiyyah" langsung dari muallif Shalawat Wahidiyah (KH. Abdul Majid Ma'roef) agar dilaksanakan oleh setiap pengamal Wahidiyah secara rutin setiap hari dalam bentuk menginfakkan sebagian harta/uang menurut kemampuan, kesadaran, dan keikhlasan masing-masing.

\footnotetext{
19 Asmik Nasikhah, wawancara (18 Agustus 2016) diperkuat wawncara dengan Nafis Azzaki, Robbi Ghoutsa, siswa kelas X TKJ SMK Ihsanniat, (16 Agustus 2016), serta Observasi peneliti
} 
6. Kebiasaan dan Keteladanan

Membangun kebiasaan yang baik sangatlah penting dalam penanaman nilai-nilai tasawuf shalawat wahidiyah. Dengan melakukukan kebiasaan-kebiasaan yang baik maka hal tersebut melekat dalam dirinya dan spontanitas menjadi karakter. Misalnya Guru Kewahidiyahan membuat kantin kejujuran, di mana siswa melayani dirinya sendiri ketika membeli makanan termasuk masalah pembayarannya.

7. Pengajian kitab al-Hikam

Pengajian kitab al-Hikam ini disampaikan langsung oleh pengasuh Pondok Pesantren At-Tahdzib, yaitu beliau Bapak KH. Ahmad Masruh Ihsan Mahin, S.Sy. Pengajian ini dilaksanakan setiap kamis legi di aula pondok. Pengajian dengan mengulas kitab al-Hikam karya syekh Ibnu Athaillah yang berisi tentang pembersihan hati dan kesucian jiwa yang juga direlasikan dengan buku kuliah Wahidiyah ini disukai siswa. Selain itu, pengajian ini juga dihadiri masyarakat sekitar. seperti Jeruk Wangi, Kasreman, Junggo, Josari, Cermenan, Kedawung dll.

8. Pendalaman Wahidiyah

Pendalaman Wahidiyah adalah kajian ilmiah kewahidiyahan yang diselenggarakan oleh Dewan Pimpinan Pusat Penyiar Sholawat Wahidiyah (DPP PSW) khususnya Badan Pembinaan Wahidiyah Pusat (BBW PSW) pada minggu akhir setiap bulan yang bertempat di Aula Kantor DPP PSW.

\section{Hasil pembentukan karakter mulia melalui internalisaasi nila-nilai tasawuf} Salawat Wahidiyah di SMK Ihsanniat Rejoagung Ngoro Jombang.

Secara umum, karakter siswa SMK Ihsanniat baik. Hal ini sebagaimana penjelasan dari Kepala Sekolah SMK Ihsanniat yaitu Bapak Ikhwanul Kirom, S.Pd., M.PdI., bahwa karakter siswa-siswi SMK Ihsanniat sangat baik. ${ }^{20} \mathrm{Hal}$ ini dilihat dari beberapa aspek:

1. Sikap

Sikap baik mereka ditunjukkan mereka kepada kepala sekolah, guru, sesama teman, dan staf-staf sekolah. Misalnya berbicara sopan, menghormat dan tawadlu' kepada para guru, taat pada perintah guru dan lain sebagainya.

${ }^{20}$ Hal ini diperkuat wawancara dengan Drs. Hariyadi, Wakasis SMK Ihsanniat, dan Ibu Kustinah, Wakakur SMK Ihsanniat, (21 Agustus 2016) dan Observasi sejak bulan Mei s.d Agustus 2016 
FITRAH Jurnal Kajian Ilmu-ilmu Keislaman

Vol. 04 No. 1 Juni 2018

Membudayakan senyum, salam, sapa kemudian salim ketika berjumpa guru dan lain sebagainya.

2. Emosi

Emosi dari para siswa juga terkontrol dengan cukup baik. Bahkan jiwa emosi-sosiologis mereka juga baik. Hal ini terlihat ketika mereka mendapat masalah atau ujian atau sesuatu yang mengejutkan, mereka mampu membillah-kannya dengan baik.

3. Kepercayaan

Dengan adanya pengajaran tentang billah, kepercayaan mereka kepada Tuhan semakin meningkat. Bahkan berdasarkan hasil wawancara dengan para siswa, mereka secara kompak menjawab bahwa kepercayaan atau keyakinan mereka kepada Tuhan semakin tebal. Hal ini terbukti jika mereka mendapat masalah mereka yaqin bahwa Allah tidak akan membebani mereka melebihi kemampuan. Selain itu, mereka menjadi lebih semangat dan tidak mudah mengeluh dalam menjalani kehidupan. ${ }^{21}$

4. Kebiasaan

Kebiasaan karakter yang muncul dari prilaku mereka bukanlah hal-hal yang tercela. Misalnya jama'ah bersama, mujahadah bersama, do'a bersama, kerja kelompok, saling bertegur sapa dengan teman dan sebagainya.

5. Konsepsi diri

Mereka juga mampu mengkonsep atau memotivasi diri dengan baik. Selain itu, siswa SMK Ihsanniat juga tidak pernah tercatat melakukan pelanggaran-pelanggaran berat yang sampai berurusan dengan pihak yang berwajib.

${ }^{21}$ Hana Masfuva Della, Siswi baru kelas XI AP SMK Ihsanniat, ia adalah seorang muallaf di akhir tahun 2015, ia pun orang yang baru mengamlkan shalawat wahidiyah. Ia menyebutkan dulu ia dan kelurganya adalah seorang pemeluk agama kristiani yang cukup kental. Kemudian hidayah Allah datang, sebulan kemudian ia bertemu dengan pengurus PSW dan ia pun akhirnya menjadi pengamal wahidiyah. Dalam proses pengamalnnya ia merasa bersyukur dan merasa banyak perubahan dalam diri dan kondisi hatinya. Seperti emosi yang lebih terkontrol, tidak meledakledak dan pastinya hati yang lebih tenang dan jiwa yang lebih tentram. (28 Agustus 2016) wawncara ini kemudian dikuatkan pula dengan Luzaimah, Siswi X AP tapel 2015/2016, Septi Jihan, siswi SMK XI AP dan Eka Kurniati, siswi XII AP tapel 2015/2016, (Wawancara: 13 Mei 2016) 
Faktor pendukung dan penghambat Internalisasi nilai-nilai tasawuf dalam Salawat Wahidiyah bagi pembentukan karakter mulia di SMK Ihsanniat Rejoagung Ngoro Jombang.

Diantara faktor pendukung dan penghambat internalisasi ini antara lain ${ }^{22}$ :

1. Faktor pendukung

a) Lingkungan

Pertama : berada di lingkungan masyarakat yang mayoritas pengamal Salawat Wahidiyah. Kedua: keberadaan pesantren at-Tahdzib. Ketiga: lokasi SMK Thsanniat berdekatan dengan Kantor DPP PSW yang sering mengadakan pembekalan dan pembinaan tentang manajemen hati melalui Salawat Wahidiyah serta materi-materi tentang kewahidiyahan.

b) Kepala sekolah, Staf Guru serta karyawan yang kompak dalam melakukan penginternalisasian nilai tasawuf Salawat Wahidiyah. Meskipun sebenarnya mayoritas guru di SMK Ihsanniat belum mengamalkan Shalawat Waahidiyah namun mereka sangat mendukung kegiatan-kegiatan kewahidiyaahan yang ada di sekolah bahkan mereka sering kali mengingatkan pengurus OSIS jika sudah waktunya Mujahadah Syahriyah misalnya.

c) Semangat dan antusiasme guru dan siswa

Antusiasme dari para guru dan siswa yang cukup besar semakin memperkuat Internalisasi nilai-nilai tasawuf dalam Salawat Wahidiyah bagi pembentukan karakter mulia di SMK Ihsanniat Rejoagung Ngoro Jombang.

4) Inovasi Guru Kewahidiyahan

Guru bak nahkoda dalam pelayaran menuju sebuah pulau atau tempaat tujuan. Begitu pula peran dan fungsinya di kelas. Ia akan berperan sebagai fasilitataor, motivator bahkan inovator dalam pembelajaran. Bagaimana siswanya mampu menyerapa apa yang ia sampaikan kemudian mengembangkan dan mengaplikasikannya dalam kehidupan sehari-hari.

Dalam ranah ini, guru kewahidiyahan cukup inovator menurut peneliti. Hal ini dapat dilihat dalam proses pembelajaran yang ia

22 Hasil wawancara dengan Asmik Nasikha, Ikhawanul Kirom, diperkuat lagi dengan pernyataan ibu Yusida, Mbak Lutfi (KTU SMK Ihsanniat), Nafis Azzaki (Kelas XII TKJ 2016/2017) dan Hana Masfuva Della (kelas XI AP) serta siti Musyarofatul Ummah, (siswi Kelas XII AP), (25 Agustus 2016). 
FITRAH Jurnal Kajian Ilmu-ilmu Keislaman

Vol. 04 No. 1 Juni 2018

laksanakan. Seperti membagi siswa SMK one by one untuk praktik menjadi pembicara di tempat umum khususnya tentang materi kewahidiyahan, atau biasa dikenal praktik kuliah wahidiyah. Tidak hanya itu, guru kewahidiyahan juga membuat "Kantin Kejujuran" sebagai sarana aplikatif dari teori kewahidiyahan yang telah diajarkan dan pengetahuan kewahidiyahan yang telah siswa dapatkan.

2. Faktor penghambat

a) Sarana dan prasarana yang kurang memadai

Dikarenakan jumlah siswa yang cukup besar yakni 221 siswa menyebabkan kegiatan-kegiatan pengamalan Salawat Wahidiyah di SMK ini kurang maksimal. Misalnya ketika mengadakan mujahadah syahriyah, karena belum mempunyai aula, biasanya acara ini dilaksanakan di kelas, sehingga sebagian siswa berada di luar. Dan siswa yang berada diluar terkadang jika cuacanya panas aatau hujan akan mengurangi kekhusyukan mereka dalam mengikuti acara ini. Terlebih acara ini dilaksanakan pukul 10.00 s.d 12.30 WIB.

b) Beberapa siswa luar yang belum menjadi pengamal wahidiyah

Hampir 7\% dari Siswa SMK Ihsanniat bukan termasuk santri pondok PA melainkan siswa-siswi dari masyarakat sekitar yang ada diantara mereka keluarganya bukanlah seorang pengamal wahidiyah. Sehingga dimungkinkan, ada pengaruh-pengaruh negatif yaang tidak disengaja mereka bawa ke sekolah. Oleh karena itu, biasanya guru kewahidiyahan akan memberikan perhatian lebih ke mereka. Misalnya mereka harus menghafalkan Salawat Wahidiyah, sering komunikasi dan sharing dengan mereka.

c) Mayoritas guru yang belum mengamalkan Salawat Wahidiyah

Jika merujuk pada pengertian pengamal Salawat Wahidiyah yang tidak sekedar hafal shalawatnya saja, maka bisa dikatakan lebih dari $50 \%$ guru dan staf di SMK Ihsanniat belum menjadi pengamal wahidiyah. Keadaan ini tentunya membuat proses internalisasi nilai tasawuf kurang maksimal terlebih jika dikaitkan dengan guru sebagai model atau figur yang akan selalu menjadi sorotan siswa sebagai idolanya. 
d) Kurangnya Kompetensi administratif guru kewahidiyahan.

Kompetensi guru sangat berpengaruh terhadap keberhasilan misi pembelajaran. Termasuk proses internalisasi nilai-nilai tasawuf Salawat Wahidiyah. Pelajaran kewahidiyahan merupakan materi yang menjabarkan secara gamblang segala hal yang berhubungan dengan wahidiyah. Sehingga kompetensi guru kewahidiyahan baik secara akademis maupun non akademis sangat dibutuhkan termasuk kompetensi administratif. Sayangnya dalam pelaksaan mulok ini guru kewahidiyahan hanya menggunakan silabus dan tidak membuat Rencana Pelaksanaan Pembelajaran (RPP).

\section{PENUTUP}

Berdasarkan pada pembahasan di atas, maka peneliti dapat mengambil kesimpulan sebagai bahwa pengamalan salawat wahidiyah di SMK Ihsanniat dikenal dengan istilah Mujahadah, baik Mujahadah yang dibakukan sampai khusus. Interalisasi nilai-nilai tasawuf dalam Salawat Wahidiyah bagi pembentukan karakter mulia siswa SMK Thsanniat antara lain melalui: Melalui Mujahadah yang dirutinkan, Anjuran selalu membaca nida' baik secara lisan maupun dalam hati, Materi kewahidiyahan dan integrasi dengan materi lain, Diklat atau upgrading Kewahidiyahan, GSDB (Gerakan Sadar berDana Box), Kebiasaan dan keteladanan, dan pengajian kitab al-Hikam dan pendalaman Wahidiyah.

Secara umum, Karakter siswa sebagai hasil internalisasi nilai tasawuf Salawat Wahidiyah di SMK Ihsanniat adalah baik. Karakter mereka dapat dilihat dari beberapa aspek: Sikap, emosi, kepercayaan, Kebiasaan dan Konsepsi diri. Mereka juga mampu mengkonsep atau memotivasi diri dengan baik. Selanjutnya, sebagai faktor pendorong internalisasi nilai-nilai Salawat Wahidiyah di SMK Thsanniat adalah lingkungan, kekompakan antara kepala sekolah, Staf Guru serta karyawan yang kompak dalam melakukan penginternalisasian nilai tasawuf Salawat Wahidiyah, semangat para guru dan siswa, dan inovasi Guru Kewahidiyahan. Sedangkan faktor penghambatnya adalah: Sarana dan prasarana yang kurang memadai, beberapa siswa luar yang belum menjadi pengamal wahidiyah, Mayoritas guru yang belum mengamalkan Salawat Wahidiyah dan kurangnya kompetesi administaratif guru kewahidiyahan. 
FITRAH Jurnal Kajian Ilmu-ilmu Keislaman

Vol. 04 No. 1 Juni 2018

\section{DAFTAR PUSTAKA}

Abdussomad, Muhammad. 2005. Penuntun Qalbu; Kiat Meraih Kecerdasan Spiritual. (Surabaya: Khalista)

Ali, Muhammad Daud. 2010. Pendidikan Agama Islam. Jakarta: Raja Grafindo Persada

Arikunto, Suharsimi. 2006. Prosedur Penelitian Suatu Pendekatan Praktik. Jakarta : Rineka Cipta

Bahreisj, Hussein . tt. Hadits Shahih Al-Jami'ush Shahih Bukhari Muslim. Surabaya: Karya Utama

Bakar, Zaki Mahdi Syech Abu. 2004. Anda Berdakwah Rasul Bersabda, Jakarta: Abla Publisher.

Basri, Hasan. 2009. Filsafat Pendidikan Islam. Bandung: Pustaka Setia

Bayyati, Ja'far. 2014. Cara Mudah Membaca Sholawat. Pekalongan: al-Mu'ammal.

Dakhlan, Sayyid Ahmad bin Sayyid Zein. 1349 H. Taqrib al-Ushul li Tashil al-Ushul fi Ma'rifah al-Rabb wa ar Rasul. Mesir: Musthofa al-Babi al-Halaby wa auladuh.

Departemen Agama RI. 2010. Al Qur'an dan Terjemahnya Al Hikmah. Bandung: CV Diponegoro.

Dimyati, Sayyid Abu Bakar alMaliki bin Sayyid Muhammad Syatha. Kifayatul Atqiya' wa Minhaj al-Asyfiya'. Ttp: DarAkhyar, t.t.

DPP PSW. 2006. Kuliah Wahidiyah:untuk menjernihkan hati dan ma'rifat Billah wa Rosulih. Jombang: Ed. XII

Kedonglo 1997. Pedoman Pokok-Pokok Sholawat Wahidiyah \& Ajaran Wahidiyah. 2009. Tuntunan Mujahadah dan Acara-acara Wahidiyah. Jombang Profil Wahidiyah. Jombang, tt.

Emzir, Analisis Data: Metodologi Penelitian Kualitatif, 2011, Jakarta :Rajawali Pers.

Furqona, Rama. 2001. Pendidikan Agama dan Akhlak Bagi Anak dan Remaja. Ciputat: Logos Wacana Ilmu. 
Gazali, Imam. 2007. Ihya' Ulum al-Din. Terj: Husein al-Hamid. Jakarta: Pustaka Amani

Hasan, Muhammad Tholhah. 2004. Islam \& Masalah Sumber Daya Manusia, Jakarta: Lantabora Press

Huda, Sokhi. 2015. Tasawuf Kultural: Fenomena Sholawat Wahidiyah. Surabaya: Imtiyaz

Husaini, Assayyid Mhmud Abdul Faidh alManafi. 1996. Himpunan Aulia dan Ulama' Tasawuf. Semarang Mutiara Ilmu.

Jailani, Syekh Abdul Qadir. 2008. Samudra Sufi. Yogyakarta: Diva Press

M. Zainuddin. 2010. Paradigma Pendidikan Terpadu. Malang: UIN Malang Press

Mahjuddin. 2009. Akhlak Tasawuf 1: Mukjizat Nabi Karomah Wali dan Ma'rifah Sufi. Jakarta: Kalam Mulia.

Mahmud, Abdul Halim. 2002. Tasawuf Di Dunia Islam. Bandung: Pustaka Setia.

Majid, Abdul dan Dian Andayani. 2011. Pendidikan Karakter Perspektif Islam. Bandung: Remaja Rosdakarya.

Margadinata, Wildana. 2010. Spiritualias Salawat. Malang: UIN-Maliki Press.

Maskawaih, Ibnu. 1398 H. Tahzib al-Akhlaq. Beirut: Mansyurat Dar Maktabat AlHayat.

Moleong, Lexy. 2003. Metodologi Penelitian Kualitatif. Yogyakarta: Rosyda Karya

Muhaimin. 2006. Nuansa Baru Pendidikan Islam. Jakarta: Raja Grafindo Persada.

Muhyiddin, Ahmad. 2005. Kecerdasan Jiwa: Rahasia Memahami dan Mengobati Sakit dalam Hati. Yogyakarta: Arruz Media

Muin, Fatkhul. 2011. Pendidikan Karakter Kontruksi Teoretik Dan Praktik. Jogjakarta : Arruz Media

Munir. Ahmad. 2008. Tafsir Tarbawi Mengungkap Pesan Al-Qur'an Tentang Pendidikan. Yogyakarta: Teras

Muslim, Muslim bin al-Hajjaj bin Muslim bin Ward, Shahih\} Muslim, CD Program Maktabah Shamilah Is\}dar Thalith.

--------, Shah\}ih Muslim, CD Ensiklopedi Hadis 9 Imam, Lidwa Pusaka, 2011. 
FITRAH Jurnal Kajian Ilmu-ilmu Keislaman

Vol. 04 No. 1 Juni 2018

Nabhani, Yusuf bin Ismail. Tt. Sa'adah ad-darain fi Ash-Shalah 'ala sayyid al-Kunain. Berut, Libanon: Dar-al-Fikr.

Nata, Abudin. 2013. Akhlak Tasawuf dan Karakter Mulia. Jakarta: Raja Grafindo Persada, 2008

N.K. Sing Dan Agwan, Teori Pembentukan Karakter. Dalam "Encyclopaedia Of The Holy Qur'an" Http://Koleksi-Skripsi.Blogspot.Com. Diakses 27 Februari 2016.

Patilima, Hamid Metode Penelitian Kualitatif, 2011, Bandung : CV Alfabeta.

Prastowo, Andi. 2011. Metode Penelitian Kualitatif. Jogjakarta: Ar-Ruzz Media

Prayitno dan Belferik Manullang. 2011. Pendidikan Karakter dalam Pembangunan Bangsa. Jakarta: Kompas Gramedia.

Qusyairi, Abul Qasim Abdul Karim Hawazin. 2007. Risalah Qusyairi. Jakarta: Pustaka Amani.

Samani, Muchlas dan Hariyanto. 2013. Konsep dan Model Pendidikan Karakter. Bandung: Remaja Rosdakarya.

Sauqi, Ahmad. 2010. Meraih Kedamaian Hidup: Kisah spiritualitas Orang Modern. Yogyakarta: Teras

Sekretariat Direktoral Jendral Pendidikan Dasar Kementerian Pendidikan Nasional. 2011. Pendidikan Karakter dalam Pembelajaran PKn. Jakarta: Kementerian Pendidikan Nasional.

Sonhadji, Ahmad. 1996. Penelitian Pendidikan. Malang: Kalimasahada Press

Sri Narwanti. 2011. Pendidikan Karakter (Pengintegrasian 18 Nilai Pembentuk Karakter Dalam Mata Pelajaran). Yogyakarta: Familia.

Subana, M. 2001. Dasar-Dasar Penelitian Ilmiah. Bandung: CV Pustaka Setia.

Sudewo, Erie. 2011. Best Practice Character Building Menuju Indonesia Lebih Baik. Jakarta: PT Gramedia

Sugiyono. 2010. Memahami Penelitian Kualitatif. Bandung:

Suharso dan Ana Retnoningsih.tt. Kamus Besar Bahasa Indonesia: Edisi lux. Semarang: Widya Karya. 
Sukmadinata, Nana Syaodih . 2010. Metode Penelitian Pendidikan. Bandung : Remaja Rosdakarya.

Sulhan, Najib. 2010. Pendidikan Berbasis Karakter. Surabaya: Jawa Poss Group.

Suranto. 2009. Metodologi penelitian dalam pendidikan system SPSS. Semarang: Ghyas Putra.

Suyanto dan M.S Abbas. 2004. Wajah dan Dinamika Pendidikan Anak Bangsa. Yogyakarta: Adicita Karya Nusa.

Syamri, Ulil Amri. 2012. Pendidikan Karakter Berbasis Al-Qur'an. Jakarta: Raja Grafindo Persada

Syarbini, Amirulloh. 2012. Buku Pintar Pendidikan Karakter. Jakarta: as@prima Pustaka.

Syukur, Amin. 2002. Menggugat Tasawuf. Yogyakarta: Pustaka Pelajar.

Taimiyyah, Syekh Ibnu. 2006. Jangan biarkan Penyakit Hati Bersemi. Jakarta: Pustaka Klasik.

2002. Risalah Tasawuf. Jakarta: Hikmah

Tanzeh. 2009. Metode Penelitian. Yogyakarta: Teras

Thomas Lickona. 2013. Pendidikan Karakter (Educating For Character). Bandung: Nusa Media.

Trianto. 2010. Model Pembelajaran Terpadu. Surabaya: Bumi Aksara

Wening, S. 2012. Pembentukan Karakter Bangsa Melalui Pendidikan Nilai. Jurnal Pendidikan Karakter Vol. 64.

Zainal Aqib. 2011. Pendidikan Karakter Membangun Perilaku Positif Anak Bangsa. Bandung: CV. Rama Widya.

Zubaedi. 2005. Pendidikan Berbasis Masyarakat (Upaya Menawarkan Solusi Terhadap Berbagai Problem Sosial). Yogyakarta: Pustaka Pelajar.

N. K. Sing Dan Agwan, Teori Pembentukan Karakter. Dalam “Encyclopaedia Of The Holy Qur'an" Http://Koleksi-Skripsi.Blogspot.Com. Diakses 27 Februari 2016. 
FITRAH Jurnal Kajian Ilmu-ilmu Keislaman

Vol. 04 No. 1 Juni 2018

\section{Uang Pangolat (Tebusan)}

\section{Dalam Perkawinan Masyarakat Tobing Julu}

Risalan Basri Harahap

IAIN Padangsidimpuan 